\title{
Biological responses in gills and hepatopancreas of Ucides cordatus (Crustacea, Decapoda, Ocypodidae) as indicative of environmental contamination in mangrove areas in Maranhão State, Brazil
}

\author{
Wanda Batista de Jesus ${ }^{1}$, Suelen Rosana Sampaio de Oliveira ${ }^{2}$ \\ Ticianne de Sousa de Oliveira Mota Andrade ${ }^{1}$, Jucimary Braga Machado Sousa ${ }^{3}$ \\ Débora Batista Pinheiro-Sousa ${ }^{4}$, Débora Martins Silva Santos ${ }^{5}$ \\ William da Silva Cardoso ${ }^{5}$ \& Raimunda Nonata Fortes Carvalho-Neta ${ }^{5}$ \\ ${ }^{1}$ Master Program in Aquatic Resources and Fisheries State University of Maranhão \\ São Luís, Maranhão, Brazil \\ ${ }^{2}$ Master Program in Oceanography State University of Maranhão, São Luís, Maranhão, Brazil \\ ${ }^{3}$ State University of Maranhão, São Luís, Maranhão, Brazil \\ ${ }^{4}$ Department of Environmental Engineering Federal University of Maranhão \\ São Luís, Maranhão, Brazil \\ ${ }^{5}$ Department of Chemistry and Biology State University of Maranhão \\ São Luís, Maranhão, Brazil \\ Corresponding author: Wanda Batista de Jesus (wandadossantosbatista@gmail.com)
}

\begin{abstract}
This study aimed to identify alterations in gills and hepatopancreas of the crab Ucides cordatus as indicative of environmental contamination in mangrove areas subject to chemical effluents from port activities in Maranhão, Brazil. Samples of gills and hepatopancreas were removed from each animal and fixed in Davidson's solution until the procedure of histological technique. The biometric data (means and standard deviations) of the specimens collected in the study areas indicated that the crabs in the reference area are significantly $(P<0.05)$ higher and heavier than the crabs collected in the potentially impacted area (port area). Gill alterations (rupture of pilaster cells, dilation of the marginal channel, cuticle rupture and necrosis) and hepatopancreas alterations (abnormal lumen, vacuolized B cells, pycnotic nuclei and necrosis) were significantly $(P<0.05)$ more frequent in crabs collected in the port area than crabs collected in the reference area. These data indicate that the health of crabs is compromised due to the pollutants present in the mangroves that surround the port area in São Marcos' Bay.
\end{abstract}

Keywords: Ucides cordatus; uçá crab; biomonitoring; biomarkers; port area; alterations; xenobiotic

\section{INTRODUCTION}

Crustaceans are part of the life and economy of many families, especially those who use the organisms as a means of subsistence (Nudi et al., 2007). Crustaceans easily accumulate pollutants present in the aquatic environment, as well as through biomagnification by the trophic chain, representing an important route of contamination to public health (Pinheiro et al., 2013). Thus, these organisms present high sensitivity to the xenobiotics available in the environment (CarvalhoNeta et al., 2019; Oliveira et al., 2019).
Ucides cordatus (Linnaeus, 1763) is considered an excellent biomonitor in the identification of mangrove pollution once it can respond to several types of changes under the influence of xenobiotics (Pinheiro et al., 2013). Also, it is an endemic species of Brazilian mangroves and plays a unique ecological role in nature (Nordhaus et al., 2006). However, the effects of xenobiotics from port activities in Maranhão on this species are still poorly understood. There are already records of heavy metals in water, sediment and mangrove in the São Luís port region (the area used in this study) that make clear the impacts of chemical po-

Corresponding editor: Claudia Bremec 
llution in this region (Furtado, 2007; Sousa, 2009; Carvalho Neta et al., 2012). As the crab is an animal that feeds on mangrove vegetation and is in direct contact with the sediment (Pinheiro et al., 2012), we chose to study this organism, as according to the literature they organisms bioaccumulating metal and respond easily to xenobiotics contaminated environment (Pinheiro et al., 2012; Duarte et al., 2016). Thus, the investigation of the effects on the health of this organism is of great relevance to the ecosystem and to the health of the people that use it for subsistence.

The histological analysis of gills and hepatopancreas of crustaceans has been increasingly recognized as a valuable tool for the evaluation of the impacts of pollutants on crustaceans (De FreitasRebelo et al., 2000; Maharajan et al., 2015; Negro, 2015; Carvalho-Neta et al., 2019). The gills are characterized as the first organ to get in contact with environmental pollution; this organ is highly sensitive to chemicals (Negro, 2015), which can lead to severe problems for the organism. The hepatopancreas of crustaceans is a very dynamic organ mainly related to the digestive functions, being responsible for most of the detoxification activity (Maharajan et al., 2015) responding with intensity to toxic substances.

The use of morphological alterations in gills and hepatopancreas (as biomarkers) of $U$. cordatus can provide information about the toxicity of chemical compounds in the environment, contributing in a fast and effective way for the monitoring of mangrove systems and port regions. They provide economically and short-term information on the effects produced by exposure to xenobiotics (De Freitas-Rebelo et al., 2000; Maharajan et al., 2015; Negro, 2015). Biomarkers are defined as the biochemical, morphological, physiological or behavioral responses of organisms to xenobiotic present in the environment (Walker et al., 2010).

In the estuarine system, mangroves occupy an extensive area and are considered an important ecosystem (Davanso et al., 2013), also participating in the recycling of biological nutrients and primary productivity. Also, mangroves serve as a nursery for many species of ecological and economic importance (Bayen, 2012). In this context, mangroves in Maranhão (Brazil) is home to several species of crustaceans, where the effects of impacts from the port complex in São Marcos' Bay on these aquatic organisms have already been reported (Carvalho-Neta et al., 2012, 2019; Sousa et al., 2013; Oliveira et al., 2019), which requires a thorough investigation of the impacts in this region (Carvalho-Neta et al., 2012, 2019; Sousa et al., 2013; Oliveira et al., 2019). This study aimed to identify alterations in gills and hepatopancreas of crabs as indicative of environmental contamination in mangroves areas subject to chemical effluents from port activities in Maranhão, Brazil.

\section{MATERIALS AND METHODS}

\section{Study area}

São Marcos’ Bay (0243'13"S, 44²1'39"W), located in the Maranhense Gulf, is classified as one of the most important estuarine area on the Brazilian coast, due to the implantation of the port complex of the State of Maranhão (1960), where about 30 companies operate the economy of the state (Souza-Filho, 2005). Therefore, it requires more detailed studies about the impacts these companies can cause in the environment and consequently in the organisms. Thus, this area was chosen and characterized in our study as a port area considered a "potentially impacted area" (Fig. 1).

The Facão Island, municipality of Raposa, is located in São José' Bay $\left(02^{\circ} 25^{\prime} 13^{\prime \prime S}, 44^{\circ} 05^{\prime} 12^{\prime \prime} \mathrm{W}\right)$ about 30 $\mathrm{km}$ far from São Luís, and it presents a mangrove ecosystem with rich fauna and flora (Santos et al., 2011). There are no major port installations or residences on the island. Therefore, it was used as a reference area in this study.

\section{Crabs samples}

Bimonthly collections of Ucides cordatus crabs were taken in the field during the dry and rainy seasons between 2016 and 2017. Only the rainy (January to June) and dry (July to December) seasons are set as default for the region (INMET, 2017). The capture of crabs was authorized by SEMA (Secretaria de Estado de Meio Ambiente e Recursos Naturais) collection permit (\#18208/2014) issued by the State Department of Natural Resources and Environment. During the collections, it was obtained 50 individuals of crabs per area (port and reference areas) with a total of 100 individuals. In order to standardize, it was chosen to capture only sexually mature males in the intermolt phase, avoiding any effects of molting and sex (Pinheiro et al., 2012).

With the help of artisanal fishermen, the crabs were collected using the braiding ("braceamento") technique, consisting of the catching of the crabs from the holes using the arm (Nordi, 1995). After that, the crabs were kept in thermal boxes and taken to the Laboratory of Biomarkers in Aquatic Organisms of the State University of Maranhão for laboratory procedures.

\section{Sediment collection}

Samples of mangrove sediments (a triplicate sampling in each area) were obtained for chemical analysis through acid digestion in a microwave oven (method 3051 USEPA, 2007). The digested solutions were filtered and analyzed by inductively coupled plasma optical emission spectrometry (ICP-IOS Optima 8300Perkin Elmer) for the analysis of arsenic, cadmium, 

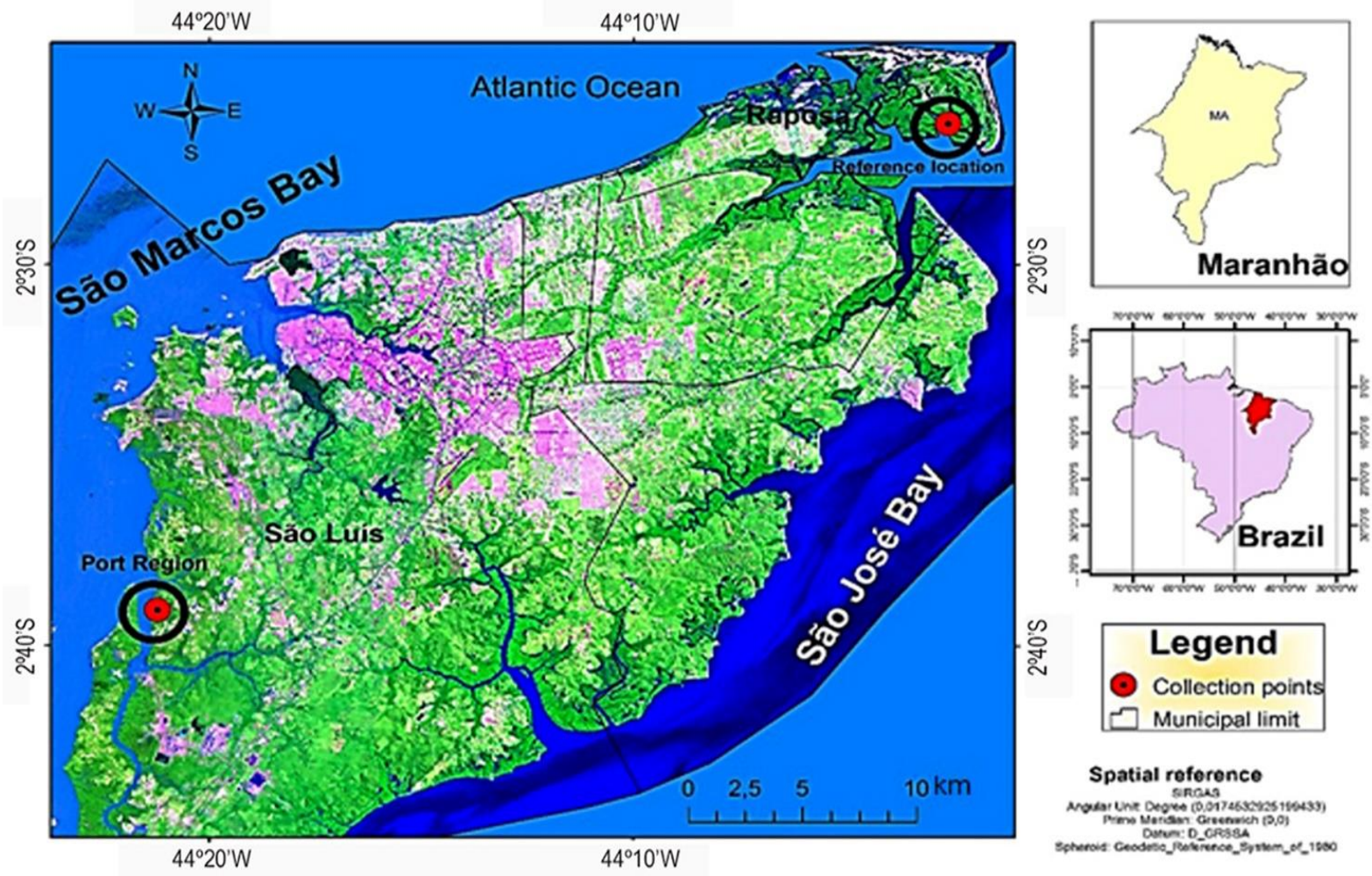

Figure 1. Location map representing sampling sites of Ucides cordatus crabs: Port Region - São Marcos' Bay; Reference area - Island of Facão, Raposa, São José’ Bay, Maranhão, Brazil.

lead, copper, chromium, nickel and zinc content and by cold vapor atomic absorption spectrometry (CVAASBuck 400A) to analyze the concentration of mercury. The detection limits calculated as three times the standard deviation of the reagent blanks and given in $\mathrm{mg} \mathrm{kg}{ }^{-1}$ for $\mathrm{HCl}$ and $\mathrm{HNO}_{3}$ extracts, respectively, were: Cd: 0.005 and 0.017 ; Ni: 0.054 and 0.018 ; Pb: 0.036 and $0.210 ; \mathrm{Cu}: 0.022$ and $0.054 ; \mathrm{Zn}: 0.3$ and 1.2 . Samples of water from the crab collection sites were collected for physical and chemical analysis, such as temperature $\left({ }^{\circ} \mathrm{C}\right)$, saturated dissolved oxygen $(\%), \mathrm{pH}$ and salinity.

\section{Biometrics data of $U$. cordatus collected in the port and reference areas}

According to Pinheiro \& Fiscarelli (2001), biometric data such as carapace width (CW) and length (CL) were taken with the aid of a precision pachymeter $(0.1 \mathrm{~cm})$. After that, the total weights (TW) of each specimen of crab were measured on a precision scale $(0.1 \mathrm{~g})$.

\section{The histological procedure of gills and hepato- pancreas samples}

In the laboratory, the specimens of $U$. cordatus were immediately dissected. Samples of hepatopancreas and gills were removed with the help of sterilized scissors.
Then, the samples were fixed in Davidson's solution for $24 \mathrm{~h}$ (Arockia-Vasanthi et al., 2014) in vials adequately identified and sealed. After $24 \mathrm{~h}$, the samples were washed and stored in $70 \%$ ethanol.

Afterward, the hepatopancreas and gills were dehydrated in increasing series of ethanol, diaphanized in xylol and impregnated with paraffin. Cross-sections of approximately $5 \mu \mathrm{m}$ thick, were stained with hematoxylin and eosin. In light microscopy, the cuts were analyzed for each organ of each animal. The modifications were photo-micrographed with an Axioskop-Zeiss microscope and quantified, according to specialized literature (De Freitas-Rebelo et al., 2000; Maharajan et al., 2015; Negro, 2015).

\section{Statistical analyses}

The biometric data were expressed as the mean and standard deviation, submitted to the normality test and were compared between the regions and between the seasons of the year by Student's $t$-test in order to verify significant differences $(P<0.05)$ in the alterations found and in the biometric data between the groups (in potentially impacted and reference areas).

The results of the alterations in the gills and hepatopancreas were expressed in percentages. A total 
of 20 hepatopancreas tubules per slide were analyzed, in which the percentage of the total number of tubules and total tubules affected were obtained. Concerning the gills, the total number of secondary lamellae and the total of each affected secondary lamella were analyzed and quantified.

\section{RESULTS}

\section{Chemical analysis of sediment}

The values of the heavy metals concentrated in the sediments of the areas analyzed in this study were different when compared between areas (Table 1), since in the port area the data of concentration of heavy metals are higher than in the area which is not influenced by the port activity (reference area). On the other hand, these values are within the standards allowed by Brazilian legislation (CONAMA Resolution 454/2012).

\section{Biometric data}

The biometric data of the specimens of Ucides cordatus analyzed in the potentially impacted area (port area) presented significantly lower values $(P<0.05)$, in both periods (dry and rainy season), when compared to the crabs collected in the reference area (Table 2).

\section{Morphological biomarkers and gill alterations}

Different types of alterations were observed in the gills of $U$. cordatus (Fig. 2). In the port area, the number of alterations identified was higher than those found in the reference area. The percentage of branchial alterations in $U$. cordatus sampled between the seasonal (rainy and drought) periods are included in Table 3 . For the rainy season, there was a higher percentage of branchial alterations in the port area. The most important alterations in the gills of crabs caught in the potentially impacted area were the rupture of the pilasters (dry season $26.4 \%$; rainy season $63.8 \%$ ), necrosis (dry season $19.7 \%$; rainy season $49.4 \%$ ) and deformation of the marginal canal (dry season $26.9 \%$; rainy season $43.1 \%)$.

\section{Alterations observed in the hepatopancreas}

Observations indicated that the percentage of the alteration in the hepatopancreas of $U$. cordatus in the port area was higher than in the crabs collected in the reference area (Fig. 3; Table 4). The percentage of alterations in the hepatopancreas of $U$. cordatus indicated that the alterations were more frequent in crabs
Table 1. Values of heavy metals in sediments $\left(\mathrm{mg} \mathrm{kg}^{-1}\right)$ from the sampling sites. LD: limits of detection. *Indicates significant differences between areas $(P<0.05)$. Port area: impacted area, Reference area: low-impacted area Brazilian Law (CONAMA \#454/2012).

\begin{tabular}{lccc}
\hline \multirow{2}{*}{ Metal } & \multicolumn{2}{c}{ Heavy metal $\left(\mathrm{mg} \mathrm{kg}^{-1}\right)$} & $\begin{array}{c}\text { Value area } \\
\text { (min.-max.) }\end{array}$ \\
\cline { 2 - 3 } & Port area & Reference area & $19-70$ \\
Arsenic & $5.9 \pm 0.2^{*}$ & $2.0 \pm 0.1^{*}$ & $1.2-7.2$ \\
Cadmium & $<0.6$ & $<\mathrm{LD}(0.6)$ & $46.7-218$ \\
Lead & $7.9 \pm 0.2^{*}$ & $2.4 \pm 0.3^{*}$ & $34-270$ \\
Cooper & $9.1 \pm 0.5^{*}$ & $2.5 \pm 0.2^{*}$ & $81-370$ \\
Chrome & $18.2 \pm 0.8^{*}$ & $5.3 \pm 0.3^{*}$ & $0.3-1.0$ \\
Mercury & $<0.05$ & $<0.05$ & $20.9-51.6$ \\
Nickel & $7.1 \pm 0.2^{*}$ & $1.9 \pm 0.1^{*}$ & $150-410$ \\
Zinc & $27 \pm 1.0^{*}$ & $10 \pm 1.0^{*}$ & \\
\hline
\end{tabular}

caught in the port area for both rainy and dry periods. However, the occurrence of alterations in the hepatopancreas of crabs varied between the rainy season and dry season for the port area $(P<0.05)$. The most important alterations in the hepatopancreas of crabs caught in the potentially impacted area were the abnormal lumen (dry season 88\%; rainy season 94\%), vacuolized B cells (dry season 77\%; rainy season 69\%), necrosis (dry season 65\%; rainy season 51\%) and pycnotic nuclei (dry season 59\%; rainy season 66\%).

\section{Comparison of alterations in gills and hepato- pancreas}

The alterations observed in crabs were much more frequent in gills than in hepatopancreas of $U$. cordatus (Fig. 4). Besides, in the port area, branchial alterations were more frequent when compared to the reference area.

\section{DISCUSSION}

The values of the concentration of heavy metals found in sediments indicated that the Ucides cordatus species might be bioaccumulating these components in their tissues, which can lead to the appearance of the defensive responses as the appearance of alterations in their organs and the diminution of their body size. Also, in this region, past studies have identified contaminations by heavy metals in water samples, mangrove sediments, vegetation and leaf dust (Carvalho-Neta $e t$ al., 2012; Silva et al., 2016), confirming the exposure of aquatic biota, contaminants such as heavy metals.

In Maranhão, mainly in the port region, a study about fish and crab biometrics showed significant differences in the sizes and weights of the individuals collected in the port area concerning a reference area 
Table 2. Means and standard deviation of the biometric data of Ucides cordatus collected during the dry and rainy seasons in the port area and in the reference area, respectively. *Indicates significant differences between sites and periods (rainy and dry $)(P<0.05)$. Total number of crabs $=100$ (50 per area). CW: carapace width, CL: carapace length, TW: total weight.

\begin{tabular}{lrrrrc}
\hline \multirow{2}{*}{$\begin{array}{c}\text { Biometric } \\
\text { data }\end{array}$} & \multicolumn{2}{c}{ Dry season } & & \multicolumn{2}{c}{ Rainy season } \\
\cline { 2 - 3 } \cline { 5 - 6 } & Port area & Reference area & & Port area & Reference area \\
\hline TW & $115.00 \pm 2.82^{*}$ & $142.50 \pm 3.53^{*}$ & & $130.00 \pm 1.41^{*}$ & $190.50 \pm 17.67^{*}$ \\
CW & $6.65 \pm 0.07^{*}$ & $6.50 \pm 0.42^{*}$ & & $7.30 \pm 0.42^{*}$ & $7.65 \pm 0.35^{*}$ \\
CL & $4.65 \pm 0.49^{*}$ & $4.85 \pm 0.49^{*}$ & & $5.20 \pm 0.28^{*}$ & $5.10 \pm 0.24^{*}$ \\
\hline
\end{tabular}
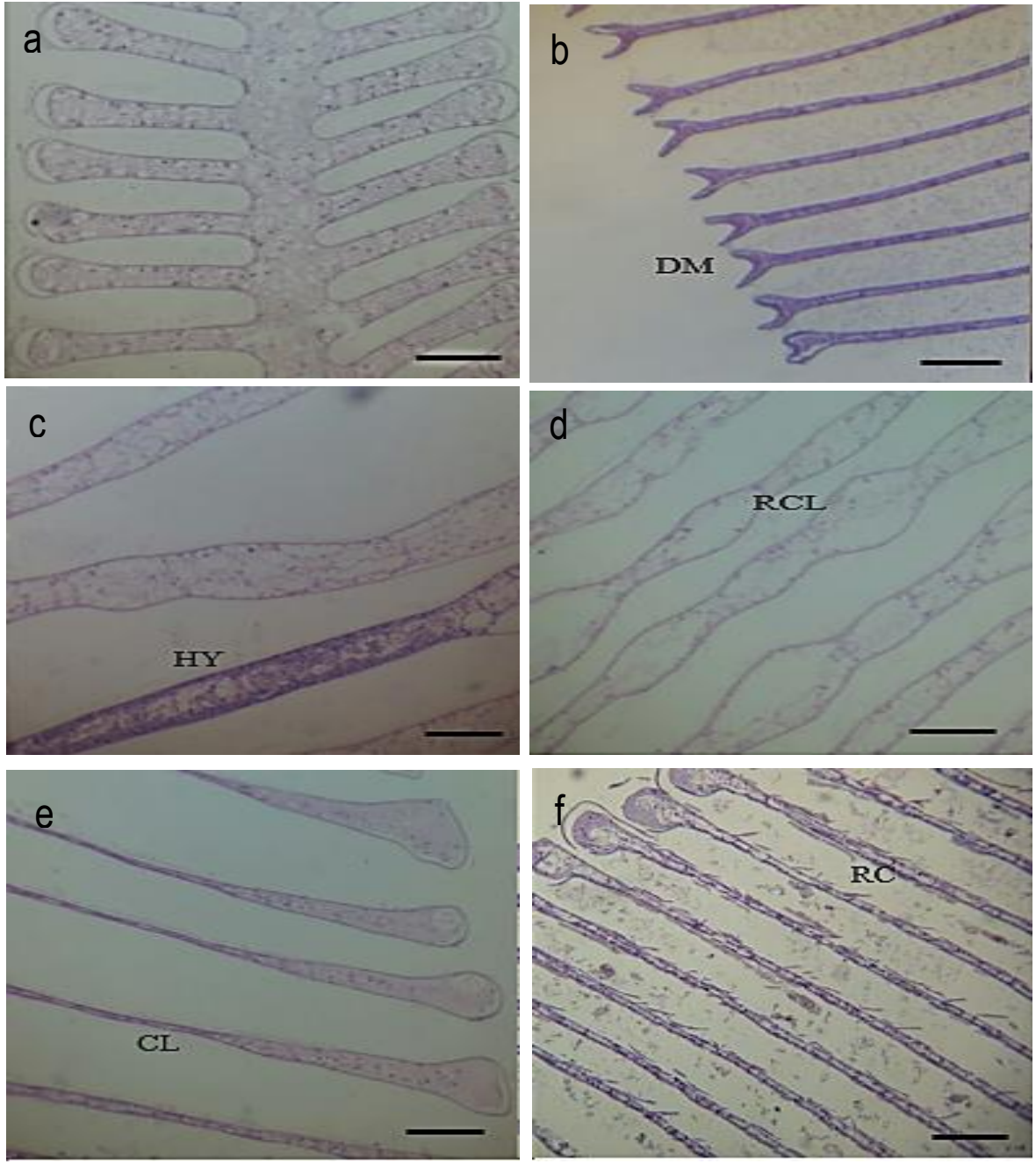

Figure 2. a) Normal gill of Ucides cordatus showing the primary lamella in the middle and the lateral lamellae, b) dilation of the marginal channel (DM), c) hyperplasia (HY), d) rupture of pilaster cells (RCP), e) lamellar collapse (CL), f) cuticle rupture (RC). Bar: $100 \mu \mathrm{m}$.

(Carvalho-Neta et al., 2014, 2019; Oliveira et al., 2019). Benetti \& Negreiros-Fransozo (2004), observed similar results, studying crabs collected in a mangrove impacted by anthropic actions, where it was observed that the crabs presented smaller sizes than those collected in less impacted areas. Moureaux et al. (2011) emphasize that the ability to deal with stress influences the amount of energy that is used in the growth of benthic invertebrates and leading to a consequent reduction in the body size of the individual. Thus, this study suggests that individuals from the port area are showing responses to stress due to the presence of xeno- 
Table 3. Percentage of lamellae alterations in the gills of Ucides cordatus collected in estuarine environments.

\begin{tabular}{lccccc}
\hline \multirow{2}{*}{ Gill alterations } & \multicolumn{2}{c}{ Dry season } & & \multicolumn{2}{c}{ Rainy season } \\
\cline { 2 - 3 } \cline { 5 - 6 } & $\begin{array}{c}\text { Port area } \\
(\%)\end{array}$ & $\begin{array}{c}\text { Reference area } \\
\text { Lamellar colapse }\end{array}$ & & $\begin{array}{c}\text { Port area } \\
(\%)\end{array}$ & $\begin{array}{c}\text { Reference area } \\
(\%)\end{array}$ \\
\hline Lamellar colapse and tissue swelling & 0.3 & 0 & & 8.0 & 0 \\
Hyperplasia & 0.3 & 0 & & 1.3 & 0 \\
Hemocyte infiltration & 0.5 & 0 & & 1.2 & 0 \\
Melanized nodules & 0.6 & 0 & & 0.5 & 0 \\
Cuticle rupture & 9.9 & 7.6 & & 0.5 & 0 \\
Detached cuticle & 10.0 & 5.8 & & 35.4 & 6.2 \\
Necrosis & 19.7 & 0 & & 49.3 & 11.9 \\
Rupture of pilaster cells & 26.4 & 16.7 & & 63.8 & 0 \\
Dilation of the marginal channel & 26.9 & 11.1 & & 43.1 & 27 \\
\hline
\end{tabular}
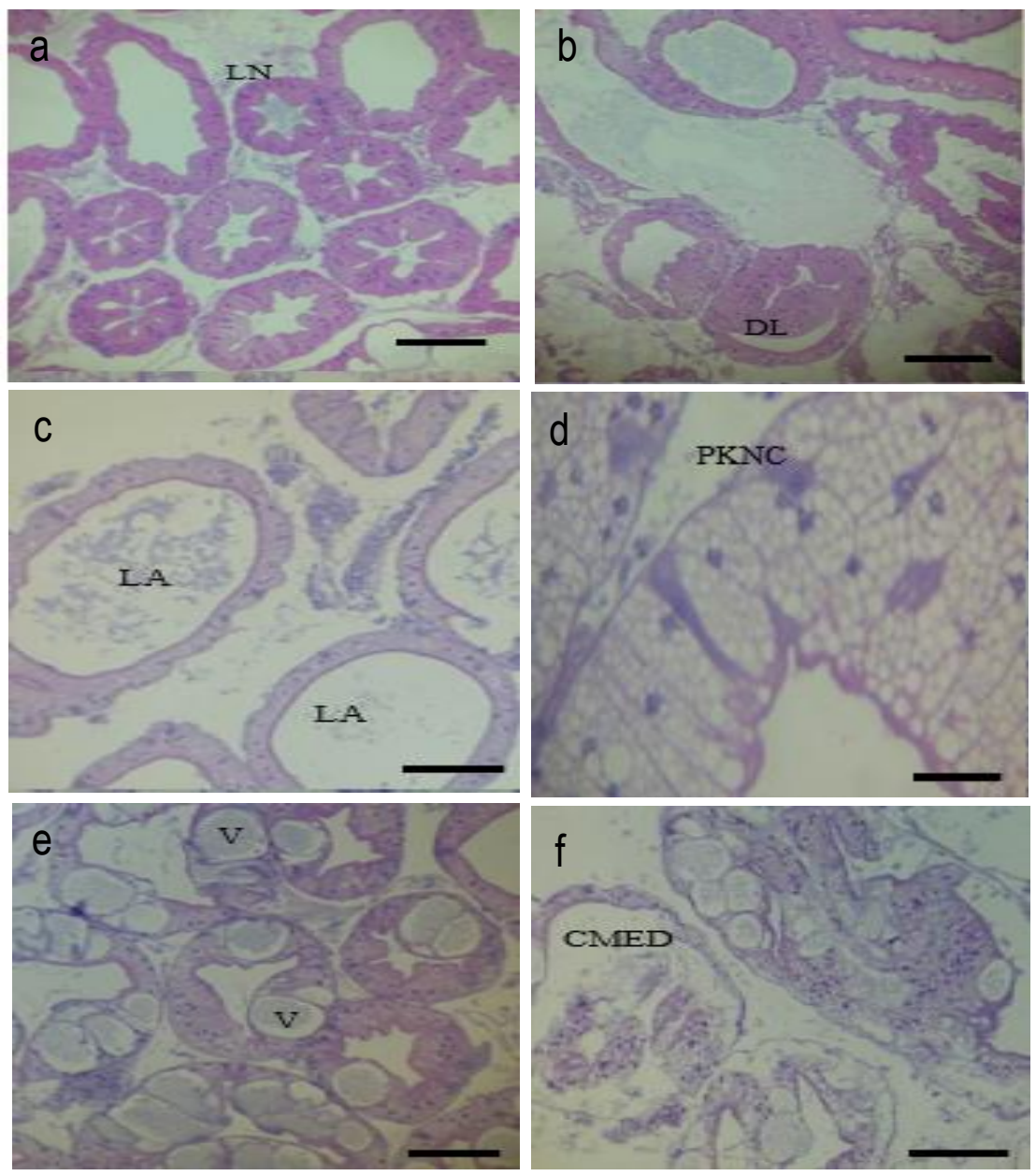

Figure 3. a) Histology of the normal hepatopancreas of Ucides cordatus demonstrating the normal star shape of the lumen $(\mathrm{LN}), \mathrm{b})$ epithelial delamination (DL), c) abnormal lumen (LA), d) pycnotic nuclei (PKNC), e) vacuolated B cells (V), f) damaged myoepithelial layer (CMED). Bar: $100 \mu \mathrm{m}$.

biotics, which may be affecting the development of crabs in the port area.
The most frequent alterations in gills of $U$. cordatus observed in this study, such as rupture of pilaster cells, marginal canal deformation and necrosis, were also 
Table 4. Percentage of alterations in the hepatopancreas of Ucides cordatus collected in estuarine environments.

\begin{tabular}{lcccccc}
\hline \multirow{2}{*}{ Hepatopancreas alteration } & \multicolumn{2}{c}{ Dry season } & & \multicolumn{2}{c}{ Rainy season } \\
\cline { 2 - 3 } \cline { 5 - 6 } & $\begin{array}{c}\text { Port area } \\
(\%)\end{array}$ & $\begin{array}{c}\text { Reference area } \\
(\%)\end{array}$ & & $\begin{array}{c}\text { Port area } \\
(\%)\end{array}$ & $\begin{array}{c}\text { Reference area } \\
(\%)\end{array}$ \\
\hline Hemocytic infiltration & 13 & 0 & & 8 & 0 \\
Apoptose & 25 & 4 & & 13 & 6 \\
Delamination of the epithelia & 36 & 10 & & 33 & 8 \\
Vacuolized B cells & 77 & 23 & & 69 & 38 \\
Damaged myoepithelial layer & 32 & 23 & & 42 & 27 \\
Necrosis & 65 & 24 & & 51 & 35 \\
Pycnotic nuclei & 59 & 41 & & 66 & 41 \\
Abnormal lumen & 88 & 55 & & 94 & 56 \\
\hline
\end{tabular}

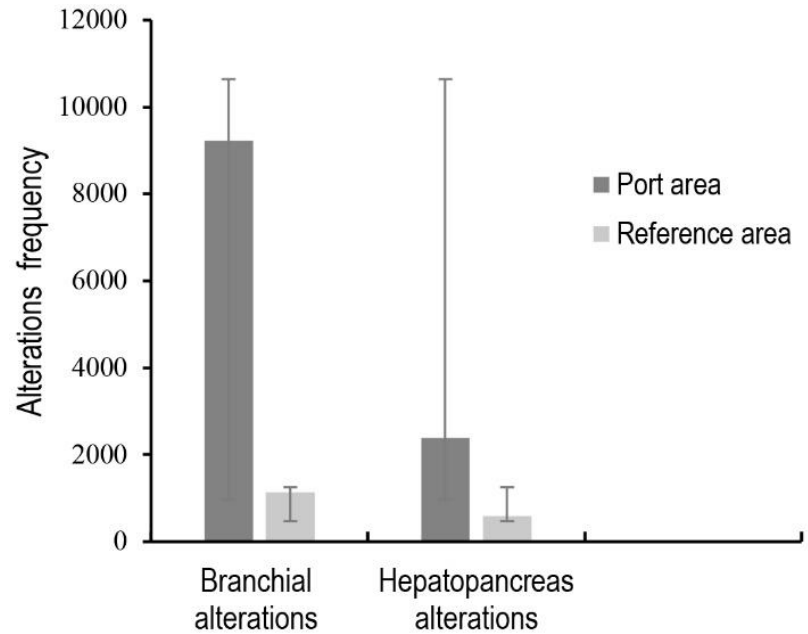

Figure 4. Comparison of alterations frequency observed in gills and hepatopancreas of Ucides cordatus in the port area (São Marcos’ Bay) and in the reference area (São José' Bay).

found in gills of crustaceans analyzed by De FreitasRebelo et al. (2000). The most important alteration in both study areas was the rupture of the pilaster cells. This type of alteration is defined as the cell break, resulting in cell death, which leads to necrosis (De Freitas-Rebelo et al., 2000). When this structure shows a normal pattern, the pilaster cells attach to epithelial cells, which will have a T-shape in the secondary lamellar.

Carvalho-Neta et al. (2012) and Oliveira et al. (2019) analyzing the sediment in the study area identified high levels of heavy metals. Also, Sousa et al. (2013) using biomarkers in catfish, Oliveira et al. (2019) and Carvalho-Neta et al. (2019), using biomarkers in crabs collected in São Marcos' Bay, identified significant histopathological responses in the gills of these organisms. These data suggest that the port area in São Marcos' Bay, which is an important habitat for crabs, is being influenced by the impacts caused by the port activities in that region. Alterations, such as hyperplasia, necrosis and rupture of pilaster cells together, can cause greater damage to the branchial tissue resulting in lamellar collapse and functional loss of the organ. According to De FreitasRebelo et al. (2000), such alteration is characterized as the reduction of hemolymph space, resulting in the collapse of the lamellar.

The gills play a significant role for the species that depend on it for respiration, osmoregulation, excretion of ions and other functions; however, when the gills perform other activities than those that have already been performed, such as the detoxification of heavy metals or pesticides, their structure may get damaged (De Freitas-Rebelo et al., 2000; Negro, 2015). Moreover, the gills are the first organs to get in contact with the aquatic environment; thus, they are subject to stress caused by contaminants present in the water. Therefore, gills have been of great importance for the study of biomonitoring being an excellent biomarker of pollution (Negro, 2015).

The alterations identified in $U$. cordatus show that the study areas on the coast of Maranhão have been impacted. However, when comparing the two environments presented here, it is observed that in the reference area, the impact is lower than in the port area. In the port area, which is considered the second largest port complex in Brazil in cargo handling, several industries may be releasing daily industrial effluents that are harmful to aquatic organisms.

In the literature, there are several reports on the histopathological effects of pollutants on crustacean gills (Bhavan \& Geraldine, 2000; Arockia-Vasanthi et al., 2014; Maharajan et al., 2015; Negro, 2015). However, are still few studies about the effects of pollutants in $U$. cordatus, especially in the state of Maranhão (Carvalho-Neta et al., 2019; Oliveira et al., 2019). Thus, detailed biomonitoring studies in the port areas are extremely necessary, especially about the specific role of each type of crab gill. 
Regarding the alterations observed in the hepatopancreas (Fig. 3) of $U$. cordatus collected in the study areas, a significant difference was observed in the frequency of alterations, with the port area presenting the higher alterations in crabs. These data corroborate with the results observed for gill alterations in the same crabs analyzed in the port region (Carvalho-Neta et al., 2019; Oliveira et al., 2019). Therefore, it is inferred that the alterations observed in different organs of crabs from the port area are due to chronic chemical contamination in the environment. Hepatopancreas of crustaceans play important roles in several metabolic processes, and exposure to chemical contaminants may lead to structural alterations (Bhavan \& Geraldine, 2000). The same types of hepatopancreas alterations observed in crabs from the port region in this study were also observed in studies carried out by Maharajan et al. (2015) for Paratelphusa jacquemontii. In this study, the abnormal lumen alteration (Fig. 3) was the most frequent alteration in the crabs collected in the analyzed areas. It is characterized by morphological alterations of the tubular epithelial cells, since the cell decreases in height, from normal columnar cells to cuboidal cells (Maharajan et al., 2015). Also, an increase of vacuolized B cells was observed (Fig. 3), which means that there was a proliferation of these cells. That may be related to the high rate of excretion of hepatopancreas, which is a storage and detoxification organ, so that it is possible to eliminate xenobiotics by increasing the number of $\mathrm{F}$ cells and converting them to B cells (Maharajan et al., 2015). Such alterations directly affect the tissue and cause damage to the cells. Thus, the alterations cited here are considered severe.

Alterations considered severe indicate irreversibly damage to cells and tissues (Bernet et al., 1999). Alterations in hepatopancreas tubule observed in crabs in the port area suggest that the integrity of the tissue may be affected by the exposure to contaminants. Studies testing different types of contaminants show that alterations in the tissues of the hepatopancreas of some crustaceans are due to their exposure to chemical contaminants (Maharajan et al., 2015; Negro, 2015). The consequences are the severe alterations identified in the present study, indicating the exposure of crabs to a polluted environment.

When comparing the frequencies of alterations observed in the gills and hepatopancreas of $U$. cordatus collected in the study areas, it was noted that the gills presented a higher frequency of alterations. Thus, it is considered a more sensitive organ than the hepatopancreas (Negro, 2015). The gills are characterized as the best organ to analyze the biomarkers (or biological responses altered due to the presence of xenobiotics) since it is sensitive, and when in direct contact with the water and contaminants, the gills respond with different structural alterations (Carvalho-Neta et al., 2019). However, it is relevant to consider that hepatopancreas has also been used as an important organ in studies with biomarkers in crustaceans of chronic contamination, and it is of fundamental importance for the metabolism of organisms (Negro, 2015). Besides that, there are four possible ways to expose crabs to a contaminant: gills, food, ingested water and skin (Galloway et al., 2002; Van Der Oost et al., 2003). Thus, even if the size of the xenobiotic molecule is larger than the exchange area in the gill, the crab will be susceptible to exposure by other metabolic pathways. Generally, in aquatic contamination studies, it is observed that in acute exposure, the gill responses are the most evident since the gills are directly exposed to xenobiotics present in the environment, responding quickly and significantly to the effects of xenobiotics (Van Der Oost et al., 2003).

On the other hand, hepatopancreas responds more slowly to the effects of xenobiotics (Carvalho-Neta et al., 2019) on the environment because they need to metabolize these compounds (and the onset of effects is later). Thus, changes in hepatopancreas are considered chronic effects changes about the acute effects changes found in gills. Therefore, both organs can be used in methodologies for the biomonitoring of port areas.

Nevertheless, there is a need to improve the knowledge about contaminants that are interfering in the physiological needs and causing histological alterations in crabs that live under the influence of the port complex activities, such as the one studied here. Besides that, the rainy season contributes to the development of changes in both organs (gills and hepatopancreas), because at this time of year, pollutants are more easily leached from the continent to the aquatic environment (Carvalho-Neta et al., 2019). Also, during this rainy season, xenobiotics present in harbor sediments (such as heavy metals) may be remobilized and bioavailable. This situation of xenobiotic bioavailability in this rainy season may influence the increase of organ changes in organisms exposed to the contaminated environment (Sousa et al., 2013). In addition, when aquatic organisms are subjected to abiotic variations (e.g., low salinity in the rainy season), they develop defensive mechanisms to maintain themselves in environments with significant variations, whether environmental or anthropic (Romano \& Zeng, 2012; Paital \& Chainy, 2013).

These data corroborate with other data of crustaceans and fish collected in the port area that is subject to stress caused by xenobiotics (Sousa et al., 2013; Carvalho-Neta et al., 2014). In other words, the smaller 
size of the crabs in the port area could indicate a decrease in the growth rate, as it has already been reported for crabs in other areas (Diele et al., 2005). A population that lives in a rich environment with food resources will have their individuals growing faster (De Oliveira et al., 2013). On the other hand, if there are not sufficient food resources (and if there are anthropogenic impacts on the area), the population may suffer from this impact due to lack of food and stress. Therefore, the port area in São Marcos Bay, which is a region of intense port activity, may influence the quantity of food available and, consequently, the maintenance of the crab populations of that ecosystem.

\section{CONCLUSIONS}

The frequency and types of alterations in gills and the hepatopancreas in the Ucides cordatus collected in the port area, and analyzed in this study, indicate that the organisms are submitted to stress caused by some contaminant, which leads to the appearance of alterations.

The biometric differences of the crabs between the study areas indicated that the crustaceans from the port area are suffering from the impacts caused by alterations in the environment, once they were smaller and less heavy when compared to the crabs collected in the area reference. Also, the comparison of alterations in gills and hepatopancreas showed that the alterations in these two organs were more extensive and significant in the crabs collected in the port area.

\section{ACKNOWLEDGMENTS}

The authors would like to acknowledge the Laboratory of Biomarkers in Aquatic Organisms (LABOAq) of the State University of Maranhão and also the Research Group on Ecotoxicology and Monitoring of Aquatic Environments (GPEMAAq) for the technical support. The Maranhão State Research Foundation-FAPEMA (Fundação de Amparo à Pesquisa e ao Desenvolvimento Científico e Tecnológico do Estado do Maranhão) for financial support.

\section{REFERENCES}

Arockia-Vasanthi, L., Muruganandam, A., Revathi, P., Baskar, B., Jayapriyan, K., Baburajendran, R. \& Munuswam, N. 2014. The application of histocytopathological biomarkers in the mud crab (Forskal) to assess heavy metal toxicity in Pulicat Lake, Chennai. Marine Pollution Bulletin, 81: 85-93. doi: 10.1016/j.marpolbul.2014.02.016
Bayen, S. 2012. Occurrence, bioavailability, and toxic effects of trace metals and organic contaminants in mangrove ecosystems: a review. Environment International, 48: 84-101. doi: 10.1016/j.envint.2012.07.008

Bhavan, P.S. \& Geraldine, P. 2000. Histopathology of the hepatopancreas and gills of the prawn Macrobrachium malcolnsonii exposed to endosulfan. Aquatic Toxicology, 50: 331-339.

Benetti, A.S. \& Negreiros-Fransozo, M.L. 2004. Relative growth of Uca burgersi (Crustacea, Ocypodidae) from two mangroves in the southeastern Brazilian coast. Iheringia, 94: 67-72. doi: 10.1590/S0073-47212004 000100012

Bernet, D., Schmidt, H., Meier, W., Burkhardt-Holm, P. \& Wahli, T. 1999. Histopathology in fish: proposal for a protocol to assess aquatic pollution. Journal of Fish Diseases, 22: 25-34. doi: 10.1046/j.1365-2761.1999. 00134.x

Carvalho-Neta, R.N.F., Torres, A.R. \& Abreu-Silva, A.L. 2012. Biomarkers in catfish Sciades herzbergii (Teleostei: Ariidae) from polluted and non-polluted areas (São Marcos' Bay, northeastern Brazil). Applied Biochemistry and Biotechnology, 166: 1314-1327. doi: 10.1007/s12010-011-9519-1

Carvalho-Neta, R.N.F., Sousa, D.B.P., de Almeida, Z., Santos, D.M.S. \& Tchaicka, L. 2014. A histopathological and biometric comparison between catfish (Pisces, Ariidae) from a harbor and a protected area, Brazil. Aquatic Biosystems, 10(12). doi: 10.1186/s 12999-014-0012-5

Carvalho-Neta, R.N.F., Mota Andrade, T.S.O., Oliveira, S.R.S., Torres, A.R., Cardoso, W.S., Santos, D.M.S., Batista, W.S., Serra, I.M.R. \& Brito, N.M. 2019. Biochemical and morphological responses in Ucides cordatus (Crustacea, Decapoda) as indicators of contamination status in mangroves and port areas from northern Brazil. Environmental Science and Pollution Research, 26(16): 15884-15893. doi: 10.1007/s11356019-04849-0

Davanso, M.B., Moreira, L.B., Pimentel, M.F., CostaLotufo, L.V. \& Abessa, D.M. 2013. Biomarkers in mangrove root crab Goniopsis cruentata for evaluating quality of tropical estuaries. Marine Environmental Research, 91: 80-88. doi: 10.1016/ j.marenvres.2013.02.006

De Freitas-Rebelo, M., Rodriguez, E.M., Santos, E.A. \& Ansaldo, M. 2000. Histopathological changes in gills of the estuarine crab Chasmagnathus granulata (Crustacea-Decapoda) following acute exposure to ammonia. Comparative Biochemistry and Physiology Part C: Pharmacology, Toxicology and Endocrinology, 125: 157-164. doi: 10.1016/S0742-8413(99) 00093-6 
De Oliveira, P.J.A., Coelho, P.A. \& Da Castiglioni, D.S. 2013. Population biology of Ucides cordatus (Linnaeus, 1763) (Crustacea, Brachyura, Ucididae) from two tropical mangroves sites on the northeast coast of Brazil. Pan-American Journal of Aquatic Sciences, 8: 89-103.

Diele, K., Koch, V. \& Saint-Paul, U. 2005. Population structure, catch composition, and CPUE of the artisanally harvested mangrove crab Ucides cordatus (Ocypodidae) in the Caeté estuary, North Brazil. Aquatic Living Resources, 178: 169-178.

Duarte, L.F., Souza, C.A., Nobre, C.R., Pereira, C.D. \& Pinheiro, M.A. 2016. Multi-level biological responses in Ucides cordatus (Linnaeus, 1763) (Brachyura, Ucididae) as indicators of conservation status in mangrove areas from the western Atlantic. Ecotoxicology and Environmental Safety, 133: 176-187.

Furtado, J.G.C. 2007. Estudo de impactos ambientais causados por metais pesados em água do mar na baía de São Marcos: correlações e níveis background. Dissertação (Mestrado em Química Analítica), Universidade Federal da Paraíba, João Pessoa, 74 pp.

Galloway, T.S., Sanger, R.C., Smith, K.L., Fillmann, G., Readman, J.W., Ford, T.E. \& Depledge, M.H. 2002. Rapid assessment of marine pollution using multiple biomarkers and chemical immunoassays. Environmental Science \& Technology, 36: 2219-2226.

Instituto Nacional de Meteorologia (INMET). 2017. Normal climatológica do Brasil 1961-1990. [http:// www.inmet.gov.br/portal/index.php?r=clima/normais Climatologicas]. Reviewed: November 28, 2018.

Maharajan, A., Narayanasamy, Y., Ganapiriya, V. \& Shanmugavel, K. 2015. Histological alterations of a combination of chlorpyrifos and cypermethrin (Nurocombi) insecticide freshwater water crab, Paratelphusa jacquemontii (Rathbun). Journal of Basic and Applied Zoology, 72: 104-112. doi: 10.1016/j.jobaz.2015.08.002

Moureaux, C., Simon, J., Mannaerts, G., Catarino, A.I., Pernet, P. \& Dubois, P. 2011. Effects of field contamination by metals $(\mathrm{Cd}, \mathrm{Cu}, \mathrm{Pb}, \mathrm{Zn})$ on biometry and mechanics of echinoderm ossicles. Aquatic Toxicology, 105: 698-707. doi: 10.1016/j.aquatox. 2011.09.007

Negro, C.L. 2015. Histopathological effects of endosulfan to hepatopancreas, gills, and ovary of the freshwater crab Zilchiopsis collastinensis (Decapoda: Trichodactylidae). Ecotoxicology and Environmental Safety, 113: 87-94. doi: 10.1016/j.ecoenv.2014.11.025

Nordhaus, I., Wolff, M. \& Diele, K. 2006. Litter processing and population food intake of the mangrove crab Ucides cordatus in a high intertidal forest in northern Brazil. Estuarine, Coastal and Shelf Science, 67: 239-250. doi: 10.1016/j.ecss.2005.11.022

Nordi, N.O. 1995. The commercialization process of the ura crab (ucides cordatus) and its reflections in the collection attitudes. Northeastern Journal of Biology, 10(1): 39-45.

Nudi, A.H., de Luca-Rebello, A., Francioni, E., de LemosScofield, A., Sette, C.B. \& Veiga, A. 2007. Validation of Ucides cordatus as a bioindicator of oil contamination and bioavailability in mangroves by evaluating sediment and crab PAH records. Environment International, 33: 315-327. doi: 10.1016/j.envint. 2006.11.001

Oliveira, S.R.S., Batista, W.S., Sousa, J.B.M., Noleto, K.S., Lima, I.M.A., Andrade, T.S.O., Cardoso, W.S. \& Carvalho-Neta, R.N.F. 2019. Enzymatic and histological biomarkers in Ucides cordatus (Crustacea, Decapoda) in an industrial on the north coast of Brazil. Bulletin of Environmental Contamination and Toxicology, 102(6): 802-810. doi: 10s00128-019-02594-1

Paital, B. \& Chainy, G.B.N. 2013. Seasonal variability of antioxidant biomarkers in mud crabs (Scylla serrata). Ecotoxicology and Environmental Safety, 87: 33-41. doi: 10.1016/j.ecoenv.2012.10.006

Pinheiro, M.A.A. \& Fiscarelli, A.G. 2001. Manual de apoio à fiscalização do caranguejo-uçá. Instituto Brasileiro de Meio Ambiente (IBAMA), Centro de Pesquisa e Extensão Pesqueira das Regiões Sudeste e Sul, Itajaí.

Pinheiro, M.A.A., Duarte, L.F.A., Toledo, T.R., Adam, M.L. \& Torres, R.A. 2013. Habitat monitoring and genotoxicity in Ucides cordatus (Crustacea: Ucididae), as tools to manage a mangrove reserve in southeastern Brazil. Environmental Monitoring and Assessment, 185: 8273-8285. doi: 10.1007/ s10661013-3172-9

Pinheiro, M.A.A., Silva, P.P.G., Duarte, L.F., Almeida, A.A. \& Zanotto, F.P. 2012. Accumulation of six metals in the mangrove crab Ucides cordatus (Crustacea: Ucididae) and its food source, the red mangrove Rhizophora mangle (Angiosperma: Rhizophoraceae). Ecotoxicology and Environmental Safety, 81: 114-121. doi: 10.1016/j.ecoenv.2012.05.004

Romano, N. \& Zeng, C. 2012. Osmoregulation in decapod crustaceans: implications to aquaculture productivity, methods for potential improvement and interactions with elevated ammonia exposure. Aquaculture, 334(1): 12-23. doi: 10.1016/j.aquaculture.2011.12. 035

Sousa, J.K.C. 2009. Avaliação de impactos ambientais causados por metais traço em água sedimento e material biológicos na Baia de São Marcos, São LuísMaranhão. Dissertação, Universidade Federal da Paraíba, João Pessoa. 
Sousa, D.B.P., Almeida, Z. \& Carvalho-Neta, R.N.F. 2013. Integrated analysis of two biomarkers in Sciades herzbergii (Teleostei: Ariidae, Siluriformes ), to assess the environmental impact at São Marcos' Bay, Maranhao, Brazil. Latin American Journal of Aquatic Research, 41: 305-312. doi: 10.3856/vol41-issue2fulltext-9

Souza-Filho, P.W.M. 2005. Costa de manguezais de macromaré da Amazônia: cenários morfológicos, mapeamento e quantificação de áreas usando dados de sensores remotos. Revista Brasileira de Geofísica, 4(23): 427-435.

Santos, P.V.C.J., Almeida-Funo, I.C.S. \& Piga, F.G. 2011. Perfil socioeconômico de pescadores do município da Raposa, estado do Maranhão. Revista Brasileira de Engenharia de Pesca, 6(1): 1-14.

Received: 24 May 2019; Accepted: 15 October 2019
Silva, A.C., França, N.S. \& Moreira, E.G. 2016. Teor metálico em um manguezal sob influência portuária, São Luís, MA. In: Almeida, Z.S. \& Oliveira, V.M. (Eds.). Avaliação ambiental no complexo portuário do Itaqui. EDUEMA, São Luís, pp. 167-195.

Van Der Oost, R., Beyer, J. \& Vermeulen, N.P.E. 2003. Fish bioaccumulation and biomarkers in environmental risk assessment: a review. Environmental Toxicology and Pharmacology, 13: 57-149.

Walker, A.N., Golden, R. \& Horst, M.N., 2010. Morphologic effects of in vivo acute exposure to the pesticide methoprene on the hepatopancreas of a nontarget organism, Homarus americanus. Ecotoxicology and Environmental Safety, 73: 1867-1874. doi: 10.1016/j.ecoenv.2010.08.013 